\title{
Hatay'ın Anavatana Katılmasının Basında Ele Alınışı: Cumhuriyet Gazetesi Örneği
}

\section{Embracing the Joining of Hatay to the Motherland in the Press: The Sample of Cumhuriyet Newspaper}

\author{
Dr. Öğr. Üyesi Lokman ZOR ${ }^{1}$
}

\begin{abstract}
$\ddot{O} \mathbf{z}$
Hatay’ın Türkiye'ye katılımı, “Kırk asırlık Türk yurdu, düşman elinde esir kalamaz” diyen Atatürk’ün belirleyip son aşamasına kadar bizzat yürüttüğü, yaklaşık yirmi yıl süren uluslararası bir mücadele sonucunda gerçekleşen Cumhuriyet tarihimizin en önemli sınır değişikliğidir. Birinci Dünya Savaşı'ndan sonra Anavatan'dan ayrı kalan Hatay, 29 Haziran 1939'da Hatay Meclisi'nin aldığı kararla Türkiye'ye katılıncaya kadar çözülmesi gereken bir sorun olarak Türkiye'deki herkesin en önemli gündemi olmuştur. Dönemin gazeteleri, Hatay (Sancak) sorununu en başından itibaren yakından takip ederek süreçle ilgili her tür gelişmeye gerek haber gerekse köşe yazısı olarak yayınlarında sıkça yer vermişlerdir. Bu bağlamda, o dönemde en çok okunan, en etkili gazetelerden biri olan Cumhuriyet gazetesinin bu konuya yaklaşımı son derece önemlidir. Dolayısıyla, özellikle Hatay'ın Türkiye'ye iltihak kararından sonra Cumhuriyet gazetesinde yer alan haber ve yorumlar, söylemsel bakımdan büyük önem taşımaktadır. Bu çalışma; Hatay’ın Anavatan'a katıldığı günlerde söz konusu olan gelişmelerin basında hangi boyutuyla ele alındığını, konunun işleniş biçimini ve konuyla ilgili yorumları dönemin en önemli gazetelerinden biri olan Cumhuriyet gazetesi örneğinde ortaya koymayı ve Cumhuriyet gazetesinin konuya yaklaşımını söylemsel boyutuyla yansıtmayı amaçlamaktadır. Bu bağlamda, Cumhuriyet gazetesinin 29 Haziran-29 Temmuz 1939 tarihleri arasında yayınlanan nüshaları taranarak Hatay'ın iltihak kararıyla ilgili haberler ve köşe yazıları, Teun van Dijk'ın eleştirel söylem analizi yöntemi ile incelenmiş, bunların arka planındaki söylem ortaya konulmustur.
\end{abstract}

Anahtar Kelimeler: Hatay (Sancak) sorunu, Cumhuriyet Gazetesi, iltihak, Hatay'ın ilhak1

Makale Türü: Araștırma

\begin{abstract}
The joining of Hatay to the Turkey which was carried out by Atatürk personally until the final stage with his statement "Forty centuries-old Turkish land cannot be captivated by the enemy", is the most important border change in the history of our Republic which came true as a result of international struggle that took place approximately twenty years. Hatay, which was separated from the Motherland after The First World War, has become the most important agenda of everyone in Turkey as a problem that should be solved until it had joined to Turkey in June 29, 1939 with the decision that was taken by the Assembly of Hatay. The newspapers of that time frequently included all kinds of progress about the process in their publishing either as news or in columns by following closely the Hatay (Sanjak) problem since the very beginning. In this context, the approach of Cumhuriyet Newspaper, which is the most-read and most efficient newspaper of that time, is extremely important. Thus, news and comments in Cumhuriyet Newspaper, especially after the decision of joining of Hatay to Turkey, carries a great importance discursively. This study, aims to reveal the progresses at issue in the days when Hatay joined to the Motherland in the sample of Cumhuriyet Newspaper, which is one of the most important newspapers of that time, in terms of how it was discussed in the press, the way it was handled and the comments about the issue and aims to reflect the approach of Cumhuriyet Newspaper to the subject in terms of discursive dimension. Within this context, the news and columns about the decision of joining of Hatay were examined by using the critical discursive analysis of Teun van Dijk, by examining the copies that was published between the dates of 29 June-29 July 1939 and the discourse in the background was put forward.
\end{abstract}

Keywords: Hatay (Sanjak) problem, Cumhuriyet Newspaper, annexation, The Annexation of Hatay

Paper Type: Research

\footnotetext{
${ }^{1}$ Niğde Ömer Halisdemir Üniversitesi, İletişim Fakültesi, lokman_zor@hotmail.com, Orcid ID: https://orcid.org/0000-0001-5352-1254.

Atıf için (to cite): Zor, L. (2019). Hatay’ın Anavatana Katılmasının Basında Ele Alınışı: Cumhuriyet Gazetesi Örneği. Afyon Kocatepe Üniversitesi Sosyal Bilimler Dergisi, 21(2), 409-418
} 


\section{Giriş}

Hatay sorunu en başından itibaren Türkiye'deki herkesin en önemli gündemi olmuş, neredeyse halkın tamamı çeşitli yollarla süreci baştan sona yakından takip etmiştir. Bu anlamda dönemin gazeteleri yaşanan süreçle ilgili halkı bilgilendirmek suretiyle ciddi bir kamuoyu oluşmasını sağlamış, konunun ele alınış ve sunuluş biçimi itibariyle son derece önemli bir işlevi yerine getirmişlerdir. Cumhuriyet gazetesinin Hatay sorununa yaklaşımı ve konuyla ilgili her türlü gelişmeyi en başından itibaren yakından takip edip farklı boyutlarıyla kısa sürede halka aktarması dikkat çekici bir gazetecilik örneğidir. Bu doğrultuda Hatay Meclisinin 29 Haziran 1939'da oy birliğiyle aldığ1 Türkiye'ye iltihak kararından sonra Cumhuriyet gazetesinde yayınlanan haber ve yorumlar, söylemsel bakımdan büyük önem taşımaktadır.

Betimsel bir araştırma olan ve genel tarama modeli ile hazırlanan bu çalışmada, Cumhuriyet gazetesinin 29 Haziran-29 Temmuz 1939 tarihleri arasında yayınlanan nüshalarındaki haberler ve köşe yazıları taranarak elde edilen veriler, A. Teun van Dijk'ın geliştirdiği eleştirel söylem analizi yöntemi ile incelenmiştir. A. Teun van Dijk'ın eleştirel söylem analizi, çoğunlukla haber inceleme ya da dilsel öğeler üzerine yoğunlaşan konulara yönelik bir söylem analizi olmasına karşın her türlü söylemdeki iktidar yapısının ve ideolojik arka planın analizi için kullanılmaktadır. Bu yönüyle medyanın tüm ürünlerinin çözümlenmesine elverişli olması bakımından öne çıkmaktadır.

Çalışmada elde edilen verilerin analiz birimini, Hatay Millet Meclisi'nin 29 Haziran 1939 günü kendini feshetmesinden sonra başlayan Anavatan'a katılma süreciyle bağlantılı haber ve yorumların somutlaşmış söylemleri oluşturmaktadır. Çalışmada örneklem olarak tesadüfî olmayan örneklem yöntemlerinden yargısal/iradi örnekleme yöntemi kullanılmıştır. Bu bağlamda, çalışmanın örneklemini, Cumhuriyet gazetesinin 29 Haziran-29 Temmuz 1939 tarihleri arasında yayınlanan nüshalarındaki haberler ve köşe yazıları oluşturmaktadır. Çalışmanın genel çerçevesini söz konusu tarihler arasındaki Cumhuriyet gazetesi nüshalarının taranarak Hatay'ın Anavatan'a katıldığı günlerde yaşanan olayların haber ve köşe yazısı olarak ele alınış ve yorumlanış biçimi ve bunların arka planındaki söylemin ortaya konulması teşkil etmektedir.

\section{Hatay Sorunu ve Hatay'ın Anavatan'a Katılması}

Birinci Dünya Savaşı sonunda Anavatan'dan ayrı kalan Hatay'ın 1939 yılında Türkiye’ye katılmasıyla Cumhuriyet Tarihi'nin en önemli sınır değişikliği gerçekleşmiştir. "Kırk asırlık Türk Yurdu, düşman elinde esir kalamaz" şiarıyla bizzat Atatürk'ün belirlediği ve yaklaşık yirmi yıl süren uluslararası bir mücadele sonucunda gerçekleşen bu sınır değişikliği, Atatürk dönemi dış politikasının en büyük başarılarından biridir. Sonucunu kendisi göremese de Atatürk'ün Hatay (Sancak) sorunuyla ilgili ortaya koyduğu azim ve kararlılık, meselenin çözümünde son derece etkin rol oynamıştır. $\mathrm{Bu}$ süreç bir anlamda, II. Dünya Savaşı'nın hemen öncesinde özellikle Avrupa'da yaşanan siyasi gelişmelerin Hatay sorununun çözümüne katk1 sağlayacak biçimde Türkiye'nin lehine değerlendirilmesiyle söz konusu olmuştur.

Hatay'ın Türkiye'ye katılması, Hatay'da uzun yıllar süren Fransız idaresinden, kısa süreli Suriye yönetiminden ve yine kısa süreli bağımsızlık sürecinden sonra gerçekleşmiştir. Misak-1 Milli sınırları içerisinde yer alan Hatay, Mondros Ateşkes Antlaşması sonrasında antlaşmanın 7. maddesi gerekçe gösterilerek Urfa, Adana, Antep ve Mersin bölgeleriyle birlikte Fransızlar tarafından işgal edilmiştir. Halkın direnişi ve kurtuluş mücadelesi sonunda bölgede tutunamayan Fransa, 20 Ekim 1921'de TBMM Hükûmeti ile Ankara Antlaşması'nı imzalamak zorunda kalmıştır. Antlaşmaya göre Fransa, Hatay dışında işgal ettiği topraklardan çekilmiş, nüfusun çoğunluğunu Türklerin oluşturduğu Hatay ise Türkçe'nin resmi dil olacağı ve Türklerin kültürlerini koruması için her türlü kolaylığın sağlanacağı özel bir yönetim kurulması şartıyla Fransız mandası altındaki Suriye'ye bırakılmıştır (Topal, 2009:2; Tekin, 2000:219).

Ankara Antlaşması hükümlerine uygun olarak 1922 yılında Hatay'da özel bir yönetim biçimi oluşturulmuş, Fransa'nın Suriye'ye bağımsızlık vermesine kadar da uygulanmıştır. Fransa ile Suriye arasında 9 Eylül 1936'da Suriye'deki Fransız mandasının kaldırılmasına yönelik bir anlaşma yapılmıştır. $\mathrm{Bu}$ anlaşmada, Hatay hakkında hiçbir hüküm bulunmaması hem Hatay'da yaşayan Türkleri, hem de Türkiye Cumhuriyeti'ni ciddi boyutta rahatsız etmiştir. Çünkü yapılan antlaşmayla 
Fransa Suriye'den çekilirken, Hatay üzerindeki yetkilerinin tamamını Suriye'ye bırakmıştır. Türkiye 9 Ekim 1936'da Fransa'ya verdiği bir nota ile bu durumu protesto ederek, Suriye'ye tanınan bağımsızlığın Hatay’a da tanınmasını istemiştir. Fransa, verdiği cevap niteliğindeki notada Hatay’a bağımsızlık vermenin Suriye'yi parçalamak anlamına geleceğini belirterek Türkiye'nin isteğini geri çevirmiştir. İki devlet arasında karşılıklı verilen notalar sonrasında Fransa'nın önerisiyle Türkiye sorunu Milletler Cemiyeti'ne taşımıştır (Atabey, 2015:195).

Bu süreçten itibaren Türkiye'de Hatay sorununun bir an önce çözüme kavuşturulmasıyla ilgili önemli bir kamuoyu oluşmuş, devletin tüm kademelerinden halka kadar herkes konuyla yakından ilgilenmeye başlamıştır. Fransa ile Türkiye arasındaki diplomatik müzakereler devam ederken Hatay Türklerinin coşku ve heyecanla yaptıkları nümayişlerin Fransız güvenlik kuvvetleri tarafından bastırılmaya çalışılması kanlı çatışmaların yaşanmasına sebep olmuştur. Yaşanan olaylar üzerine Atatürk, Fransa'ya gözdağı içerikli bir mesaj vermek üzere 1937 yılının Ocak ayında Konya'ya oradan da Ulukışla'ya giderek çeşitli temaslarda bulunmuş, bölge halkıyla görüşmeler yapmıştır (Karakoç, 2009:104).

Milletler Cemiyeti'nin duruma el koymasından sonra İsveç Temsilcisi M. Sandler'in başkanlığında oluşturulan heyet, Hatay'da yaptığı çalışmalardan sonra konuyla ilgili tespit ve önerilerini rapor olarak (Sandler Raporu) Milletler Cemiyeti'ne sunmuştur. Bu sürecin devamında Milletler Cemiyeti aracıllğıyla Fransa ile Türkiye arasında yapılan görüşmeler Cenevre'de anlaşmaya bağlanmış; Hatay'ın "ayrı bir varlık" olarak içişlerinde serbest, dış işlerinde Suriye'ye bağlı hukuki varlığını sağlayan, Türkiye-Suriye sınırını belirleyen ve Hatay'ın toprak bütünlüğünü iki ülkenin ortak garantisi altına alan anlaşma imzalanmıştır. Aynı gün ayrıca, Türkiye ve Fransa'nın görüşleri alınarak Hatay için hazırlanan anayasa da Milletler Cemiyeti tarafından kabul edilmiştir (Dayı, 2002:337; Atabey, 2015:196).

Ne var ki, bu antlaşmaya rağmen sorunun çözümü söz konusu olmamıştır. Türkiye ile Fransa arasında seçim sistemi konusunda görüş ayrılığının ortaya çıkması, anayasayı uygulama konusunda Fransa'nın engeller çıkarması ve Hatay'daki Fransız sömürge idaresinin Arapları Türk toplumunun aleyhine kışkırtması gibi sebeplerle Türkiye ile Fransa arasındaki gerginlik yeniden tırmanmıştır. Geçen bir yıla rağmen somut bir adım atılamaması ve yaşanan gerginlikler üzerine Atatürk, sağlık durumunun kötü olmasına ve doktorların tüm itirazlarına rağmen 20-24 Mayıs 1938'de Mersin ve Adana'ya gidip topçu ve piyade birliklerini denetleyerek Türkiye'nin bu doğrultudaki kararlılığını ortaya koymuştur (Dayı, 2002:338). İlerleyen günlerde Hatay'daki Hıristiyan mahallesinde bir Türkün öldürülmesi, Türklerin infialine sebep olmuş, Hıristiyan mahallesine yönelik saldırı girişimi zorlukla bastırılmıştır. Türkiye, yaşanan olayları Fransa ve Milletler Cemiyeti nezdinde protesto etmiş, seçim çalışmaları ertelenerek Milletler Cemiyeti Komisyonu'nun Hatay'dan ayrılması söz konusu olmuştur. Bütün bunların devamı niteliğinde Haziran ayı sonlarında Türkiye sınıra 30 bin kişiden oluşan bir askeri kuvvet sevk etmiştir (Akçora, 1995:397).

Türkiye'nin bu sert ve kararlı yaklaşımı ve Avrupa'daki siyasi durumun iyice gerginleşerek yeni bir dünya savaşının eşiğine gelinmiş olması Fransa'nın Hatay sorununda Türkiye'ye karşı daha 1lımlı ve yumuşak bir tutum takınmasına sebep olmuştur. Bu süreçten sonraki gelişmeler çoğunlukla Türkiye'nin istek ve beklentileri doğrultusunda, Türkiye lehine gerçekleşmiştir.

Fransa'nın Hatay politikasındaki yumuşamaya paralel olarak Türk ve Fransız askeri heyetleri arasında görüşmeler başlamış, 26 Haziran 1938 tarihinde karşılıklı uzlaşıyla Türk ve Fransız hükümetleri statü ve Anayasa'nın tatbikini temin etmek için Hatay'da ilk seçim işlerinin kontrolünü birlikte uygulamaya karar vermişlerdir. Günlerce süren görüşmeler sonunda 3 Temmuz 1938'de Türk Fransız Askeri Antlaşması ve 32 maddeden oluşan ek protokol imzalanmış, bunu Paris'te başlayıp Ankara'da neticelenen görüşmeler sonucunda 4 Temmuz 1938'de imzalanan Türkiye - Fransa Dostluk Antlaşması izlemiştir (Dayı, 2002:339).

İmzalanan Askeri Antlaşma ve 32 maddelik ek protokol gereğince, Hatay'ın toprak bütünlüğü ile siyasal statüsünün iki devlet tarafından korunması, sükûn ve asayişin sağlanması amacıyla 6 bin kişilik kuvvet oluşturulması, bunlardan bin kişinin Hatay'dan, geri kalan kısmının da her iki devletin 2500 'er kişilik askerî kuvvet göndermesiyle temin edilmesi kabul edilmiştir. Süreci yakından takip 
eden Atatürk, anlaşma haberini alır almaz Türk kuvvetlerinin Hatay’a girmesini emretmiştir. Bunun üzerine öncü birlikler 4 Temmuz, Kurmay Albay Şükrü Kanatlı kumandasındaki esas birlikler de 5 Temmuz 1938 günü Payas ve Hassa üzerinden Hatay topraklarına girmiştir (Sarınay, 1996:411).

Türkiye ile Fransa arasında yapılan antlaşmalardan ve varılan uzlaşılardan sonra Fransa'nın olumsuz yaklaşımı dolayısıyla uzun zamandan beri yapılamayan Hatay seçimleri, Türk ve Fransız otoritelerinin ortak denetiminde ve güvenlik garantisi altında iki kademeli olarak gerçekleştirilmiştir. 24 Ağustos 1938 'de tamamlanan seçimlerde 40 milletvekilliğinden 22 milletvekilini Türkler, 9 milletvekilini Alevi cemaati, 5 milletvekilini Ermeni cemaati, 2 milletvekilini Arap Sünni cemaati, 2 milletvekilini Rum Ortodoks cemaati kazanmıştır. Seçimlerin ardından Meclis, 2 Eylül 1938 günü ilk toplantısını gerçekleştirmiş ve bütün milletvekilleri Türkçe yemin etmişlerdir. Bu ilk toplantıda ayrıca, ismi "Hatay Cumhuriyeti", resmi dili Türkçe ve Arapça olarak belirlenen yeni devletin Cumhurbaşkanlığı'na Atatürk'ün de adayı olan Tayfur Sökmen, Başbakanlığı'na da Dr. Abdurrahman Melek getirilmiş̧ir (Akçora, 1995:399).

Bağımsız bir Hatay Cumhuriyeti'nin kurulması Hatay sorununu Türkiye açısından büyük ölçüde çözüme kavuşturmuş olsa da tamamen çözmemiştir. Zira gerek Hatay gerekse Türkiye, Hatay'ın anavatana bağlanmasından yana bir tutum içerisindedir. Bir yıla yaklaşan bağımsızlık sürecinde Türkiye ile yakın işbirliği içerisinde bir yandan Hatay'daki sosyal hayatı düzenlemeye yönelik adımlar atılırken bir yandan da Anavatan'a katılma isteği sıklıkla dile getirilmiştir. Türkiye tarafindan da olumlu yaklaşım gören bu istek, Fransa ile Türkiye arasındaki ilişkilerin yeniden gerilmesine sebep olmuştur.

Fransa, Hatay'ın Türkiye'ye iltihakını engellemek için çeşitli girişimlerde bulunmuşsa da gerek Türkiye'nin bu konuda geri adım atmamasından gerekse Avrupa'da yaşanan gelişmelerden dolayı ciddi şekilde köşeye sıkışmıştır. Almanya'nın 15 Mart 1939'da Çekoslovakya'yı, İtalya'nın 7 Nisan 1939'da Arnavutluk'u işgal etmeleri üzerine Avrupa'daki tüm dengeler değişmiş II. Dünya Savaş1 eşiğine gelinmiş olmasından dolayı Fransa İngiltere'nin de devreye girmesi sonucu Türkiye'nin Hatay konusundaki isteklerini kabullenmek zorunda kalmıştır. Yapılan görüşmeler sonucunda 23 Haziran 1939'da Türkiye ile Fransa arasında Hatay Antlaşması imzalanmıştır. Bu antlaşmayla; Türkiye ile Suriye arasındaki toprak sorunlarının kesin çözümü niteliğindeki Türkiye-Suriye sınırı, Hatay Devleti'ni Türkiye sınırları içerisinde bırakacak şekilde belirlenmiş; Fransa, Hatay'ın Türkiye'ye katılmasını kabullenmiş; Türkiye'nin Suriye toprak bütünlüğ̈̈ne sayg1 göstermesi ve içişlerine karışmaması garanti altına alınmış; Fransız askerlerinin bir ay içinde Hatay’ı terk etmesi kararlaştırılmıştır (Sarınay, 1996:422).

Antlaşmanın imzalanmasından sonra Hatay Devleti Meclisi 29 Haziran 1939'da oy birliğiyle Türkiye'ye iltihak kararı alarak kendini feshetmiş, böylece Hatay Cumhuriyeti'nin varlığına son verilmiştir. Bu gelişme üzerine Türkiye de 7 Temmuz 1939'da çıkardığı "Hatay Vilayeti Kurulmasına Dair Kanun"la merkezi Antakya olmak üzere Hatay ilinin kurulması ve Türkiye'ye bağlanması işlemini kesinleştirmiştir (Karakoç, 2009:110).

Yeni kurulan Hatay ilinin yönetimi Türkiye Fevkalade Komiseri Cevat Açıkalın tarafından yürütülürken 18 Temmuz 1939'da Hatay Egemenlik Cemiyeti Genel Sekreteri ve Emniyet Genel Müdürü Şükrü Sökmensüer, Hatay'ın ilk valisi olarak atanmıştır. Fransa ile yapılan antlaşma ve ek protokoller gereğince Hatay'daki Fransız hak ve malları Türkiye tarafından satın alınmış, Hatay davasında mücadele ederek şehit düşenlerin ailelerine maaş bağlanmış ve Hatay halkından isteyenlerin altı ay içinde Suriye ve Lübnan vatandaşı olabilmesine hak tanınmıştır (Sarınay, 1996:423).

Böylece Hatay sorunu, Atatürk'ün belirleyip başlatarak son sürecine kadar da bizzat yürüttügü akılcı bir dış politika stratejisiyle ve barışçıl yolla Türkiye'nin istediği biçimde nihayetlendirilmiştir. Atatürk'ün ifadesiyle "Kırk asırlık Türk yurdu", 23 Temmuz 1939 sabahı Türk ve Fransız birliklerinin katıldığı bir törenle Fransız bayrağının indirilip yerine İstiklal Marşı eşliğinde Türk bayrağının çekilmesinin ardından son Fransız askerlerinin de çekilmesiyle yeniden ve kati bir şekilde Anavatan'a bağlanmıştır (Tekin, 2000:228). 


\section{Hatay'ın Anavatana Katılışının Cumhuriyet Gazetesindeki Görünümü}

Hatay Meclisi'nin oy birliğiyle Türkiye'ye iltihak kararı aldığ 29 Haziran 1939'daki oturumdan sonra 29 Temmuz 1939'a kadar Cumhuriyet gazetesinde toplam 33 haber 6 köşe yazısı yayınlanmıştır. Bu haberlerden büyük bir kısmı Hatay'ın Anavatan'a katılımına yönelik kanuni düzenlemeleri ya da devlet organları tarafindan yapılan hazırlıkları ele alan ve bir iki paragraftan oluşan kısa haberlerdir. Bunların dışında özellikle ilk günlerde yayınlanan haberler ve köşe yazıları Cumhuriyet gazetesinin konuya yaklaşımı bağlamında değerlendirme bakımından son derece önemlidir.

Bu yönüyle, 30 Haziran 1939 tarihli gazetenin ilk sayfasında "Hatay Devleti tarihe karıştı" üst başlığıyla Hatay Meclisi'nin iltihak kararı halka duyurulmakta, bu kararın 30'dan fazla imza ile teklif edilip coşku ve sürekli alkışlarla kabul edildiği belirtilmektedir. Haber içeriğinde kararın sebep olduğu coşku ve mutluluk çeşitli biçimlerde sık sık ifade edilmekte Meclis’teki oylama sonrasında konuyla ilgili yapılan konuşmaların vekiller tarafından dakikalar boyu coşku ve heyecanla alkışlandığı belirtilmektedir. Haberin 7. sayfadaki devamında Meclis oturumun sonlandırılmasından sonra İstiklal Marşı'nın okunduğu, Hatay Bayrağının indirilerek yerine Türk Bayrağının çekildiği söylenmektedir. Aynı heyecan ve coşkunun Meclis dışındaki Hatay halkı tarafından da yaşandığı, izci ve esnaf teşekküllerinin yanı sıra on binlerce halkın askeri temsilcilik ve fevkalade komiserlik önünde coşkuyla şükran tezahüratları yaptı̆̆ı, şenlik ve gösterilerle şehri dolaştığ 1 ifade edilmektedir.Tam sayfa olarak yayınlanan haber metninde ayrıca Fransızların Hatay'dan ayrılma hazırlıklarına başladığı, iltihak kararıyla ilgili kanun tasarılarının Türkiye Büyük Millet Meclisi’ne gönderildiği bilgisi verilmekte, Fransa ile yapılan antlaşmanın tam metni yer almaktadır.

Aynı günkü gazetede, Abidin Daver imzasıyla yayınlanan, "Türk-Fransız ittifakının ilk tesirleri” başlıklı 26 Haziran 1939'da Paris'ten gönderilen bir mektup niteliğindeki köşe yazısı da iltihak kararının alınmasına zemin hazırlayan Türkiye Fransa Antlaşması'nın Fransa'daki etkilerini ele almaktadır. Abidin Daver'in, Fransa'da görüştüğü bir gazeteci, bir yüzbaşı, bir otel müdürü ve halkın çeşitli kesimlerinden insanların Türkiye ile Fransa arasında imzalanan antlaşmadan duydukları memnuniyeti yansıtan köşe yazısı, genel olarak Fransızların Türklere ve Türkiye'ye nasıl büyük bir hayranlık duyduklarını, düşman olarak nasıl çekindiklerini ve müttefik olmaktan büyük memnuniyet hissettiklerini aktarmaktadır (Cumhuriyet gazetesi, 30 Haziran 1939).Köşe yazısı Hatay'ın iltihakından önce yazıldığı için bu konuya doğrudan değinmemekle birlikte süreci Fransa açısından yansıtması ve karşı cephenin bakış açısını ortaya koyması bakımından önem taşımaktadır.

İltihak kararının tesiri Cumhuriyet gazetesinin 1 Temmuz 1939 tarihli yayınında da devam etmektedir. Gazetenin ilk sayfasında "Meclis, Hatay Antlaşmasını dün ittifakla tasdik etti” başlığıyla yayınlanan haberde Hatay'ın Anavatan'a katılmasına yönelik kanun tasarısının TBMM tarafından kabul edildiği belirtilmektedir. Haberin 9. Sayfadaki devamında TBMM'deki oturum esnasında yapılan konuşmaların detayları aktarılarak, Atatürk'ün Adana seyahati sırasında “Kırk asırlık Türk yurdu esir kalamaz" sözünü söylediği anıyı anlatan Kocaeli milletvekili İbrahim Diblan'ın yanı sıra birçok vekilin konuşmaları aracılığıyla Atatürk'ün Hatay meselesine gösterdiği ehemmiyet özellikle vurgulanmaktadır. Haberin detayında, Tayfur Sökmen ile İsmet İnönü arasındaki telgraflar aynen yer almaktadır. İnönü’nün gönderdiği telgrafta "Hatay meclisinin kararı, Hataylıların yirmi sene süren kahramanca mücadelesinin neticesidir..." dediği belirtilirken, Sökmen'in ise "Coşkun tezahürat içerisinde bugün Hatay meclisinin kapanmastyla yirmi senelik milli mücadele tarihi şerefle, saadetle, sevinçle hitama ermiş bulunuyor..." dediği ifade edilmektedir.

Yunus Nadi'nin aynı günkü "Hatay Meclisinin en kutlu kararı" isimli başyazısı da hamaset içerikli bir üslupla Hatay'ın Anavatan'a katılmasının önemini ifade ettikten sonra gerek Hatay'da gerekse Türkiye'de yarattığı coşkuyu yansıtmaktadır. Hataylıların Fransız kuvvetlerinin tamamen çekileceği 23 Temmuz'u beklemeyerek büyük bayram şenliği yapmaya başladıklarını, yirmi yıllık bir hasret hayatının nihayete ermesinin verdiği mutluluk, coşku ve sevinci zapt etmenin mümkün olmadığını, en büyük bayramlarını kutlamakta haklı olduklarını belirterek tebrik etmektedir. Yunus Nadi, köşe yazısında ayrıca, ortaya çıkan sonucun "sulhu ve hakkı koruyacak bir ittifakın tarafi olarak" Fransa için de bir iftihar vesilesi olduğunu vurgulamaktadır (Cumhuriyet gazetesi, 1 Temmuz 1939). 
$\mathrm{Bu}$ günlerde yayınlanan dikkate değer bir köşe yazısı da 3 Temmuz 1939 tarihli gazetede "İtalyan matbuatının neşriyatı karşısında" başlığıyla, Nadir Nadi tarafından kaleme alınmıştır. Nadir Nadi, köşe yazısında, bazı İtalyan gazetelerinde Hatay meselesine yönelik İtalya'nın duyduğu rahatsızlığı yansıtan "Türk İngiliz anlaşması Akdeniz Paktı'na aykırı bir harekettir", "İngiltere Arap memleketlerini Türkiye ile paylaşmak istiyor. Hatay bu işin başlangıcı addedilebilir", "Hatay'ı Türklere vermekle Fransız Hükümeti Milletler Cemiyeti prensiplerini hiçe saymış, insanlık haklarını çiğnemiştir" gibi bir takım haberlere yer vermiştir.Köşe yazısının devamında bütün bu iddialara ayrı ayrı cevap veren Nadir Nadi, gazeteciliğin özgürce yapılamadığı bir ülkede yayınlanan bu tür haberlerin, ancak faşist yönetimin beklentileri doğrultusunda yapılmış olabileceğini ve terbiye kaidelerine uymadığını son derece sert bir dille ifade etmiştir.

Aynı konu ertesi günkü "Hatay davamızda telakki tarzları" isimli başmakalesinde Yunus Nadi tarafından da ele alınmış, İtalya ve Almanya gibi totaliter devletlerin yakın zamana kadar Türkleri haklı gösterdikleri Hatay konusunun barışçıl biçimde halledilmesi karşısında ağız değiştirmesi samimiyetsiz siyasetlerinin delili olarak yorumlanmıştır. Yazının devamında Türkiye'nin haklılığına vurgu yapılarak duyulan kaygıların yersiz olduğu ifade edilmiştir (Cumhuriyet gazetesi, 4 Temmuz 1939).

Cumhuriyet gazetesinin 4 Temmuz 1939 tarihli yayınında Hatay'ın Anavatan'a katılmasıyla ilgili birkaç haber yer almaktadır. "Hatay muazzam şenlikler için hazırlık yapıyor" başlıklı haberde katılım dolayısıyla hazırlanacak şenliklerden ve hazırlıklardan; "Sabık Hatay Devlet Reisi Ankara'ya Geldi” başlıklı haberde Tayfur Sökmen ile Abdurrahman Melek'in Ankara'ya gelip TBMM'de görevlerini devam ettirmeye başladıklarından bahsedilmektedir. Ayrıca bir ya da ikişer paragraftan oluşan kısa haberler halinde Hatay'ın Anavatan'a katılmasından dolayı Kars, Artvin ve Kelkit'te düzenlenen şenlikler ve halkın coşkusu aktarılmaktadır.

Hatay'ın Anavatan'a katılım kararının uluslararası yankılarını da dikkatle takip eden Cumhuriyet gazetesi, özellikle yurt dışındaki muhabir ve yazarları aracılı̆̆ıyla bu doğrultudaki yaklaşımları haber ya da köşe yazısı olarak sıcağı sıcağına kamuoyuna aktarmıştır. Bu bağlamda; 5 Temmuz 1939 günkü gazetenin 3. Sayfasında T. Cemil imzasıyla ve "Hatay'ın ilhakını Suriye nasıl karşıladı?" başlığıyla, Beyrut Mektupları isimli köşe de yayınlanan yazı, Suriye ve Lübnan özelinde Arap dünyasının konuya yaklaşımını ortaya koyması açısından ilgi çekicidir. Hatay'ın iltihakının Suriye ve Lübnan'da olağan karşılandığını belirten köşe yazısı, Türkiye ve Fransa arasında bir süreden beri devam eden müzakerelerin bu sonucun göstergesi olduğunu dolayısıyla söz konusu ülkeler tarafindan bunun beklendiğini ifade etmektedir. Bu yüzden gerek Şam'da gerekse Beyrut'ta yayınlanan Arap gazetelerinin, hadiseyi sükûnetle karşıladığı, Türkiye'ye yönelik saldırıya girişmeden "Kuvvetin Hakka mağlubiyeti" ya da "Şehit Sancak" gibi başlıklar atarak gelişmeleri kamuoyuna aktardığı belirtilmektedir.

Türkiye Büyük Millet Meclisi, 7 Temmuz 1939 günkü oturumunda Hatay ilinin kurulmasına yönelik yasayı kabul etmiş, buna ek olarak Hatay'ın idari ve adli işleriyle ilgili bir takım düzenlemeler için kararlar almıştır. Bu sayede Hatay’ın Anavatan'a bağlanma süreci kesinleşerek tamamlanmıştır (Akçora, 1995:402). Söz konusu yasa ile ilgili haber, Cumhuriyet gazetesinin 8 Temmuz 1939 tarihli yayınında yer almıştır. Farklı konuların ele alındığı meclis oturumuyla ilgili yapılan haberin içeriğinde Hatay'daki adli ve idari düzenlemelere yönelik kanunların alkışlar arasında kabul edildiği sonrasında da Tayfur Sökmen'in söz hakkı alarak bir konuşma yaptığı belirtilmektedir.

Hatay'ın il olarak Türkiye'ye bağlanması yasalaştıktan sonra Cumhuriyet gazetesi, 10 Temmuz 1939'da kamuoyuna iki önemli gelişmenin haberini duyurmuştur. Bunlardan biri; TürkiyeSuriye hudutlarını tespite memur komisyonun, Türkiye-Suriye sınır taşını koymak üzere, Hatay-Suriye sınır taşını kaldırdığı ve Ankara'ya götüreceği haberidir. Diğer haber ise Hatay'ın ilk Valisi olarak atanan Emniyet Genel Müdürü Şükrü Sökmensüer'in tayin emrini almak üzere İstanbul'dan Ankara'ya hareket ettiği haberidir. Haber içeriğinde Vali'nin tayin emrini aldıktan sonra derhal Hatay'a hareket edeceği ve 23 Temmuz' da Hatay'da düzenlenecek olan büyük şenliklerde Cumhuriyet Hükûmeti'nin en büyük mülkiye memuru sıfatıyla yer alacağı ifade edilmektedir.

Gazetenin sonraki günlerde çıkan bütün yayınlarında Hatay'la ilgili gelişmeleri duyuran en az bir habere yer verilmiştir. Tayfur Sökmen'in Hatay Bayrağı ve devlet binasının anahtarını 
Cumhurbaşkanı İsmet İnönü'ye teslim ettiği ve İnönü'nün Ekim ayında Hatay'1 ziyaret edeceği (Cumhuriyet gazetesi, 11 Temmuz 1939); 23 Temmuz'da Hatay'da yapılacak kurtuluş bayramına hazırlıkların devam ettiği (Cumhuriyet gazetesi, 12 Temmuz 1939); Hatay'daki Fransız askerlerine ait malzemelerin tahliyesine ve resmi kurumların Türk yetkililere devredilmesine başlandığ 1 (Cumhuriyet gazetesi, 13 Temmuz 1939) gibi haberler bu süreçte çıan haberlerden bazılarıdır.

Yaşanan gelişmelere rağmen konuyla ilgili uluslararası birtakım tepkiler kesilmemiştir. $\mathrm{Bu}$ bağlamda, İtalya Hükümeti, 10 Temmuz 1939'da Fransa'ya bir nota vererek, 1920 San Remo Konferansı devletlerinden biri olarak görüş ve onayı alınmadan Türkiye ile yapılan antlaşmanın manda amacına ters düştügünü ileri sürüp protesto etmiştir (Sarınay, 1996:424). Cumhuriyet gazetesi bu olayı 14 Temmuz 1939 tarihli yayınında "İtalya'nın notası, Roma Hükümeti Hatay'ın ilhakını tanımak istemiyor" başlığıyla haberleştirmiş, haber içeriğinde notanın Fransa tarafından lakayt bir şekilde karşılandığı ve ciddiye alınmadığı ifade edilmiştir. Elde edilen veriler doğrultusunda tamamen yoruma dayalı bir yaklaşımla yansıtılan haberde, Fransa'nın notayla ilgili hiçbir muamele yapmayacağı, en fazla notanın alındığına dair cevap verileceği ihtimali üzerinde durulmuştur.

Hatay'ın il olması yasalaştıktan sonra süratle adli ve idari teşkilatlanmalar ve bunlara yönelik atamalar yapılmaya başlanmış, Cumhuriyet gazetesinde yayınlanan haberler aracıllğıyla bu doğrultudaki her bir gelişme kamuoyuna aktarılmıştır. Tayfur Sökmen'le yapılan bir görüşmenin de yayınlandığ 15 Temmuz 1939 tarihli gazetede adli kadro atamaları, 16 Temmuz 1939 tarihli gazetede de İçişleri Bakanlığı tarafından yapılan atamalar yer almış ayrıca Şükrü Sökmensüer'in göreve başlamadan önce yaptığı temaslarla ilgili bilgi verdiği bir görüşme yayınlanmıştır. Gazetenin 19 Temmuz 1939 günkü sayısında bir gün önce Hatay'a gidip görevine başlayan Vali Şükrü Sökmensüer'in konuşması haberleştirilmiştir. Özellikle Ermeni ve gayrimüslimlerin Hatay'ı terk etmesi için başlatılan Suriye kaynaklı tahriklere cevap niteliğindeki konuşma, haberin metninde detaylı şekilde yansıtılmıştır. Tüm vatandaşlar arasında eşitlik, adalet ve özgürlük ilkelerine bağlı kalınarak muamele edileceğinin vurgulandığı konuşmayı aktaran haber, Sökmensüer'in sözlerine şiddetli tezahürat gösterildiğinin belirtilmesiyle sonlandırılmıştır.

Bu konu, ertesi gün Nadir Nadi'nin "Hatay'daki Ekalliyetler" isimli başmakalesinde de ele alınmıştır.Hatay'ın Anavatan'dan ayrı kaldığı süreçte yaşanan hasreti etkili bir biçimde ifade eden Nadir Nadi, Hatay'da yaşayan azınlıklar hakkında bir çift sözü olduğunu belirterek kötü propagandalara alet olup paniğe kapılmak suretiyle yurtlarını terk etmeyi düşünenlere sükûnet telkin etmektedir. Şükrü Sökmensüer'in, Cumhuriyet esaslarının tüm vatandaşlar hakkında seyyanen tatbik edileceğini vurguladığı konuşmanın bir kısmını aynen aktaran Nadir Nadi, başmakalesinin son kısmında şunları ifade etmektedir: "Görülüyor ki Cumhuriyet hükümetinin maksadı temiz ve açıktır. Yurdun en tenha köşelerine kadar esen hürriyet rüzgârı bir kisim vatandaşları kavramasın bu, bizim prensiplerimize uyar bir şey değildir. Hatay'da oturan ekalliyetlere tavsiye ederiz, yirmi senden beri takip etmedikleri yeni Türkiye'yi iyi ve çabuk tanısınlar. Imparatorluk devrinde yapılmış hatalar varsa, onlar unuttuk. Dikkat edecekleri nokta bundan sonra adam gibi yaşamak, şu ve bu propagandaya kapılarak, ileride yalnız kendilerine zararlı olacak hareketlerden sakınmaktır. Bu noktaları göz önünde bulundurdukları takdirde, güzel Hatay'daki yuvalarında mesut bir hayat sürmemeleri için ortada hiçbir sebep yoktur" (Cumhuriyet gazetesi, 20 Temmuz 1939).

Cumhuriyet gazetesinin sonraki günlerde,24 Temmuz 1939'a kadarki yayınlarında Hatay'da yapılacak olan kutlamanın hazırlıklarıyla ilgili haberler yer almıştır. Bu bağlamda, kutlama programının detayları; TBMM'den, resmî kurumlardan, CHP'den, farklı illerden temsilci olarak kimlerin katılacağı; kutlama dolayısıyla Cumhuriyet meydanına Atatürk heykelinin dikilmesi; Fransız askerlerinin şehirden ayrılma hazırlıkları, kutlama için Hatay'a giden davetlilerin karşılanması gibi konular haberleştirilmiştir.

23 Temmuz 1939 'da Hatay'a giden heyet ve temsilcilerin yanı sıra mahşeri bir kalabalığın katılımıyla yapılan ve Hatay'ın Kurtuluş Bayramı kabul edilen kutlama törenleri üç gün üç gece sürmüş, bu arada Fransız askerleri de Hatay'dan çekilmiştir (Akçora, 1995:402). Hatay'ın Anavatan'a bağlanmasının verdiği coşku ve sevinç yurdun dört bir tarafında benzer şekilde düzenlenen programlarla da kutlanmıştır. Cumhuriyet gazetesi, Hatay' da ve diğer illerde yapılan bu kutlamaları 24 Temmuz 1939 tarihli sayısında "Hatay'ın kat'i ilhakı, Milli bayram yurdun her tarafinda tesid edildi" 
başlığıyla duyurmuştur. Haber içeriğinde, “Antakya kışlası üzerinde 21 seneden beri asıll bulunan Fransız bayrağının yerine Türk bayră̆ının çekilişi merasimi çok heybetli ve müheyyic (heyecan verici) olmuştur...”, denilerek merasimin ayrıntıları hamasi bir anlatımla aktarılmıştır. Öyle ki, “... Bunu müteakip şerefli sancağımızın, Hatay kışlası direğine çekilmekte olduğu görülmüş, bu sirada yer yerinden oynamıştır. Saat tam 7’yi 47 dakika 35 saniye geçe, coşkun bir halk seli Türk'e has vakarını muhafaza ederek kışlanın kapısina hücum etmiş, klşla birkaç saniyede kadınlı, erkekli on binlerce insan tarafindan işgal edilmiştir. Manzara çok muhteşem olmuştur. ...” gibi ifadelerle törene dair tasvirler yapılmıştır. Haber metninde Fransız askerlerinin Hatay'dan ayrılışı da yine aynı üslupla “... Önünde General olduğu halde zabitler otomobillerle, efrat kamyonlarla Halep'e doğru yola çıkmışlardır. Son Fransız tankı köşseyi dönerek gözden kaybolduğu sırada yüz bin insanın kışla üstünde dalgalanan şanlı bayrağımızın karşısındaki tezahüratı bu tarihi günün en klymetli hatırası olmuştur. ..." şeklinde tasvir edilmiştir. Haberin devamında İskenderun, İzmir, İstanbul, Ankara ve ülkenin farklı yerlerinde düzenlenen kutlama törenlerinin de ayrıntıları verilmiştir.

Fransız askerlerinin çekilmesi ve Hatay'ın kurtuluşuna yönelik törenlerin haberleri sonraki günlerde de yayınlanmaya devam etmiş, bu doğrultuda üç gün boyunca düzenlenen yemek, resepsiyon, tören v.b. etkinlikler, halkın katıldığı şenlik ve gösteriler coşku dolu bir anlatımla ve fotoğraflarla desteklenerek sık sık gündeme taşınmıştır. Bu haberler; "Hatay'da bayram devam ediyor" (Cumhuriyet gazetesi, 25 Temmuz 1939), "Hatay'ımıza kavuşurken, Hatay'ın bayramı" (Cumhuriyet gazetesi, 26 Temmuz 1939), "Meclis heyetinin Hatay'da ziyaretleri" (Cumhuriyet gazetesi, 26 Temmuz 1939), "Hatay'a giden heyet geliyor" (Cumhuriyet gazetesi, 27 Temmuz 1939) başliklariyla yayınlanmışıtır.

Bu süreçte son olarak 28 Temmuz 1939 tarihli gazetede Hatay Mektupları köşesinde "Fransız kumandanları Antakya'dan nasıl ayrıldı?" başlı̆̆ıyla Mekki Said Esen'in bir köşe yazısı yayınlanmıştır. Esen, mektup olarak gönderdiği yazısında gönüllü olarak kışlanın temizlenmesi görevini üstlenen Hataylı kadınların özveriyle yaptığı çalışmalardan bahsederek, halkın yaşadığı coşku ve heyecanın devam ettiğini belirtmektedir. Yazısında son derece abartılı bir üslup kullanan Esen, "Hala meydana toplanarak klşlayı bir kere ziyaret için günün ve gecenin her saatinde sıra bekleyenler görülüyor. Ta uzaklardan ellerinde kurbanlarlyla gelenlerin haddi hesabr yok: 'Nezrettik, sözümüzü yerine getireceğiz' diyorlar. Tahtalar öpenler, duvarlarl yalayanlar var. Klşlaya 21 senelik hasretten sonra şanlı Türk bayră̆ının çekildiği andaki büyük heyecan, bütün canlıllğıyla her tarafta yaşıyor" demektedir. Mekki Said Esen, yazısının devamında 23 Temmuz günü Hatay'dan ayrılan Fransız kumandanlarıyla Hatay Valisi Şükrü Sökmensüer ve Albay Şükrü Kanadlı arasındaki dostane vedalaşmayı nakletmiş, ortaya çıkan sahneyi Türk-Fransız dostluğunun mesut tecellisi olarak nitelendirmiştir.

\section{Sonuç}

Türkiye ile Fransa arasında 20 Ekim 1921'de imzalanan Ankara Antlaşması'yla Misak-1 Milli sınırları dışında kalan Hatay, Fransa'nın hâkimiyetinde özel yönetimli bir statüye kavuşturulmuştur. Atatürk'ün belirleyip ölümüne kadar da bizzat yürüttüğü akılcı bir dış politika sonucunda önce bağımsızlık kazanan Hatay, 29 Haziran 1939'da Hatay Meclisi'nin aldığı kararla da Anavatan'a bağlanmıştır. Hatay sorunu en başından itibaren Türk basının ilgi odağı olmuş, dönemin gazeteleri konuyla ilgili gerek Türkiye'de gerek Avrupa ve Ortadoğu'da gerekse Hatay'da söz konusu olan her türlü gelişmeyi ilgiyle takip edip kamuoyuna aktarmıştır.

Hatay Meclisi'nin oybirliğiyle aldı̆̆ı Türkiye’ye katılma kararı ve sonrasındaki süreç, diğer gazetelerde olduğu üzere Cumhuriyet gazetesinde de gerek haber gerekse köşe yazısı olarak yoğun şekilde işlenmiştir. İltihak kararının alındığı 29 Haziran'dan itibaren Cumhuriyet gazetesinde Hatay'ın Anavatan'a katılımıyla ilgili olarak bir ayda 33 haber 6 köşe yazısı yayınlanmıştır.

Dönemin, yaşanan sürecin ve konunun taşıdığı hassasiyete binaen, haberlerin ve köşe yazılarının neredeyse tamamı milli bir davanın ele alınışına yönelik bir bakış açısıyla oluşturulmuş ve kamuoyuna aktarılırken buna uygun bir dil ve anlatım kullanılmıştır. Hiç şüphesiz bu yaklaşımın arkasındaki en önemli unsur, Türkiye'nin Hatay meselesindeki haklılı̆̆ 1 olmuştur. Bununla birlikte Cumhuriyet gazetesinin iktidarın yanında yer alan yayın çizgisinin de etkisi büyüktür. Haber metinlerinde yer verilen devlet yetkililerine ait konuşma ve beyanatlarla haber metinleri, ifade biçimi 
bakımından bire bir örtüşmektedir. Dolayısıyla haberler ve köşe yazıları, ulusal bir gazetenin milli bir davaya yaklaşımının biraz daha ötesinde, belirgin bir biçimde iktidar ideolojisinin söylemleri doğrultusunda oluşturulmuştur.

Yayınlanan haber ve köşe yazılarında dikkat çeken önemli bir nokta da çeşitli yollarla sık sık vurgulanan 20 yıllık hasret ve özlemdir. Kırk asırlık Türk yurdunun bir parçası olarak dışarıda kalmış olan vatan parçasının ve orada yaşayan halkın kurtuluşuna yönelik duyulan özlem ya da Hataylıların Anavatan'a kavuşma adına duydukları yüksek şiddetli arzu, ulusalcı bir yaklaşımla sık sık ifade edilmektedir. Bu kutlu kavuşmanın sebep olduğu sevinç ve coşkunun özünde ulusal bütünlüğün sağlanmış olması fikri yatmaktadır. Hem haberlerde hem de köşe yazılarında hamasetin ön plana çıktığı, belirgin bir sevinç ve coşkunun yansıtıldığı, genel olarak abartılı bir anlatım söz konusudur. Öyle ki, süreçle ilgili bilgi aktarılırken ortaya koyulan yaklaşım, Fransızların bile iltihak kararından memnun olduğunu düşündürecek niteliktedir. Suriye, Fransa ve diğer ülkelerin konuya yaklaşımının ve sürece ait gelişmelerin aktarılmasında Türkiye cephesinden bakılması, olayların Türkiye lehine değerlendirilmesi tüm haber ve köşe yazılarının içeriğinde belirgin şekilde hissedilmektedir.

Bütün bunlardan hareketle, Cumhuriyet gazetesinin 29 Haziran 1939'da Hatay'in Anavatan'a katılım kararıyla söz konusu olan süreci hem siyasi hem de toplumsal boyutuyla yansitmasının ardındaki ideolojik yaklaşımın genel anlamda ulusalcı bir söylem içerdiğini ifade etmek mümkündür.

\section{Kaynaklar}

Akçora, Ergünöz (1995). Hatay'ın Anavatan'a İlhakının Türk Dıı̧ Politikasındaki Yeri, Atatürk Araştırma Merkezi Dergisi, 32/Temmuz: 379-405.

Atabey, Figen (2015). Hatay'ın Anavatana Katılma Süreci, Avrasya Uluslararası Araştırmalar Dergisi, 7(4): 192-209.

Day1, S. Esin (2002). Hatay Devleti ve Hatay'ın Anavatana Kat1lmas1, Atatürk Üniversitesi Türkiyat Araştırmaları Enstitüsü Dergisi, 19: 331-340.

Karakoç, Ercan (2009). Atatürk'ün Hatay Davası, Bilig Dergisi, 50: 97-118.

Sarınay, Yusuf (1996). Atatürk'ün Hatay Politikası -II- (1938-1939) , Atatürk Araştırma Merkezi Dergisi, 35(12): 407-454.

Tekin, Mehmet (2000). Hatay Tarihi: Osmanlı Dönemi, Atatürk Dil-Tarih Yüksek Kurumu Atatürk Kültür Merkezi Yayını, Ankara.

Topal, Coşkun (2009). Sancak (Hatay) Sorunu ve İkinci Dünya Savaş1 Öncesi Süreçte Arap Kamuoyundaki Etkileri, Trakya Üniversitesi Sosyal Bilimler Dergisi, 2(11): 1-16.

\section{İncelenen Gazeteler}

Cumhuriyet, 30 Haziran 1939.

Cumhuriyet, 1 Temmuz 1939.

Cumhuriyet, 3 Temmuz 1939.

Cumhuriyet, 4 Temmuz 1939.

Cumhuriyet, 5 Temmuz 1939.

Cumhuriyet, 7 Temmuz 1939.

Cumhuriyet, 8 Temmuz 1939.

Cumhuriyet, 10 Temmuz 1939.

Cumhuriyet, 11 Temmuz 1939.

Cumhuriyet, 12 Temmuz 1939.

Cumhuriyet, 13 Temmuz 1939.

Cumhuriyet, 14 Temmuz 1939.

Cumhuriyet, 15 Temmuz 1939.

Cumhuriyet, 16 Temmuz 1939.

Cumhuriyet, 19 Temmuz 1939.

Cumhuriyet, 20 Temmuz 1939.

Cumhuriyet, 24 Temmuz 1939. 
Cumhuriyet, 25 Temmuz 1939.

Cumhuriyet, 26 Temmuz 1939.

Cumhuriyet, 27 Temmuz 1939.

Cumhuriyet, 28 Temmuz 1939. 